\title{
Research on the Influence and Demand of PPP Mode on Project Cost Management
}

\author{
Gao Tian ${ }^{1}$, Yinyi Lin ${ }^{1,2}$, Wang Xiang ${ }^{2}$ \\ ${ }^{1}$ School of management, Tianjin University of Technology, Tianjin, 300384, China \\ ${ }^{2}$ School of management, Tianjin University, Tianjin, 300072, China \\ Email: 1933106879@qq.com
}

Keywords: PPP, Project Cost Management, PPP Project Supervision

\begin{abstract}
Since 2013, when China's economic growth has entered into a shift, the risks of debt exposure have emerged, and the PPP has become the main way of infrastructure construction. With the promotion of China's PPP project, the investment of PPP projects is out of control, which leads to the increase of government expenditure responsibility. Through summarizing the background of PPP and the current situation of China's PPP project construction cost management, this paper constructs the project cost management system for China PPP project based on the experience of foreign PPP project management. Research indicated that the current engineering cost valuation basis, the quota system on PPP project is still applicable, but from the system supply, supply of method, the PPP project cost management system should be adjusted and perfected.
\end{abstract}

\section{Introduction}

China's economic growth has entered a "new normal", with economic growth slowing further and fiscal revenue growth entering a shift. At the same time, the urbanization process is accelerating, and the investment demand for public infrastructure construction is increasing. For a long time, governments at all levels of China have provided "comfort letter" and "guarantee letter" to finance and build infrastructure through platform companies, hiding a large risk of government debt $^{[}$. In unsustainable "land finance", under the background of high local government debt, how to reduce the pressure on government finances, actively expand new financing channels, and become a new urbanization resolve huge investment of the contradiction between the demand and insufficient financial input key.

The third plenum of the 18th central committee mentioned "allowing social capital to participate in urban infrastructure investment and operations through franchising". The PPP model has since spread across China's infrastructure and utilities. Countries carry out the PPP mode aims to shift used to rely on "government endorsement" guarantee of investment and financing system, the social capital through franchising, commissioning operations, including the exercise is part of the government expenditure responsibilities, and to project future proceeds to repay part of the debt, reduce the financial pressure. Social capital serves the PPP project with its own life-cycle PPP project management capability, and improves the construction quality, operation service quality and supply efficiency of infrastructure and utilities. But in the process of private supply, need in the profit-seeking nature of "social capital" and "provide high-quality public services for the common people" to create a balance between, approach is to give full play to the government's supervision and regulation, method is to build a covers the whole life period of the project contract system, incentive compatibility and performance appraisal system, project governance and project management mechanism, break the predicament of today's public goods production, to provide public goods effectively create new situation. 


\section{Current situation of project cost management of China's PPP project}

\subsection{The project cost of PPP project is out of control and increase government expenditure responsibility}

Judging from the current implementation status of PPP projects, the intervention of social capital is generally before and after project approval. At this time, the project cost form is investment estimation or design estimate. The project cost of PPP project is government payment, feasibility gap subsidy and PPP product or service pricing basis, as well as the premise of government procurement of social capital and signing of a PPP project contract, as the basis for government spending.

2.2 The project company is the management body of the PPP project, and the government has the supervision responsibility

Social capital is the main investor. An important function of PPP mode is to carry out project financing, and special purpose company is the investment subject of PPP project. Final decision main body is the government. The PPP project should be authorized by the government project implementation agencies and social capital to submit project proposal and feasibility study report, on the basis of social capital of project proposal and feasibility study report should be left to the government auditing through the rear can implement. The project company administers itself under the supervision of the government. The project company is the main body of the PPP project, and the project company is responsible for the overall management of the capital, construction and project management of the project.

\subsection{According to the design responsibility and the engineering construction subject choice project cost management path}

According to the project of the public goods attribute and the government responsibility division, cope with the present stage the PPP project engineering cost management and project evaluation work, its valuation way according to the quantities bill valuation rules and different categories, different parts of the project the corresponding list valuation standard or method is carried out.

\subsection{PPP model and DBB (Design-Bid-Build) model of pricing features comparison}

After investigation and research, the current pricing basis and method of project cost are applicable to PPP project. However, compared with the DBB model, PPP model cost management work early, high precision, professional cross-strong, covering a long time.

\subsection{The project company is mainly responsible for the cost control in the PPP project}

The project company signs the construction contract with the construction unit at the construction stage, and the subsequent cost management is based on the construction contract. The project company directly supervises the expenses incurred on the construction site. In the settlement and final stage, the project company audits the actual cost incurred by the project, and deducts some expenses that are not real, resulting in the final project final accounts.

\section{Project Cost Management System Construction for China PPP Project}

\subsection{Comparison and Analysis of the Main Body of PPP Project and Government Investment Project}

The main body of PPP project and government investment project management is compared with the investment, decision-making and management, as shown in the following table 1.

By contrast, the PPP project adopts the management mode of the owner and the supervising unit, and the owner hires the supervising unit to take charge of the site management. Under the PPP model, the government is transformed from a provider of public goods to a regulator. All construction and business activities of the project company should be conducted under the 
supervision of relevant government departments.

Table 1 Two forms of contrast

\begin{tabular}{|c|c|c|}
\hline Compare items & Government investment projects & PPP projects \\
\hline Investors & $\begin{array}{c}\text { Government (all kinds of financial } \\
\text { funds) }\end{array}$ & $\begin{array}{l}\text { Social capital alone or jointly } \\
\text { funded with the government, the } \\
\text { government-funded shareholding } \\
\text { ratio should be less than } 50 \%\end{array}$ \\
\hline $\begin{array}{c}\text { Decision-making } \\
\text { subject }\end{array}$ & $\begin{array}{l}\text { Proposed by the owners units } \\
\text { (government departments, } \\
\text { institutions) to apply for } \\
\text { construction, submitted to the } \\
\text { NDRC, the financial sector for } \\
\text { approval before the project. }\end{array}$ & $\begin{array}{l}\text { Can be initiated separately by the } \\
\text { government or social capital, no } \\
\text { matter who initiated the reform and } \\
\text { approval of the department to be } \\
\text { approved only after approval }\end{array}$ \\
\hline $\begin{array}{l}\text { Management } \\
\text { subject }\end{array}$ & $\begin{array}{l}\text { National Development and Reform } \\
\text { Commission (project } \\
\text { decision-making), the Ministry of } \\
\text { Finance and the National Audit } \\
\text { Office (funding and supervision), the } \\
\text { various administrative departments } \\
\text { (project supervision) and the } \\
\text { implementation unit (the use of } \\
\text { funds) }\end{array}$ & $\begin{array}{c}\text { The project company manages } \\
\text { itself under the government's } \\
\text { supervision }\end{array}$ \\
\hline
\end{tabular}

\subsection{Clear PPP project belongs to the scope of government investment projects}

PPP projects provide differentiated support from the government's fiscal funds. The public nature of a PPP project determines that it should be governed by the government.

PPP projects belong to public projects and are concentrated in the industries closely related to the national economy and the people's livelihood. It is of public interest. Even if PPP issues are constructed and operated by social capitalists, the government departments still shoulder enormous social and political risks in the event of major problems

\subsection{Develop guidelines for guidance on cost management for applicable PPP projects}

Due to the large number of construction areas involved in the PPP project, the valuation basis adopted by various projects during the implementation phase has varied and lacks a unified management system and system and is based on the valuation of industries.

\subsection{Establish PPP project investment appraisal system}

The forecast data of the preliminary project affects the substantive content of the PPP contract. Construction cost data is the calculation base of government pay or financial expenditure. The data at various stages of the PPP project determine the government and the public's spending responsibilities. The construction of PPP project investment review system needs accurate and effective evaluation basis support.

\subsection{Develop applicable PPP project evaluation methods and parameters}

The VfM method adopted by China can only meet the purpose of relevant departments to realize the declaration of "entry into the PPP project library", and can not achieve the purpose of evaluating which of the traditional government investment mode and the PPP mode is better. Therefore, it is suggested that the VfM evaluation be taken as a prerequisite step in the analysis of the economic cost effectiveness, together with cost benefit analysis to determine whether a specific PPP project is reasonable and feasible. Finally, a VfM evaluation can be made for infrastructure construction, public utilities supply, complete and credible PPP project evaluation system. 


\subsection{Establish accurate estimates of PPP projects}

During the operation of a PPP project, the estimation of project investment as a basis for calculating the VfM of the PPP project and the estimated expenditure for the financial budget will affect the formation of fixed assets. The Ministry of Finance has recently stepped up the supervision of the government in purchasing service-oriented PPP projects with the aim of strictly controlling the formation of government debts. However, most of the PPP projects are involved in the feasibility study stage. Of the projects where the payment mechanism is government-subsidized or feasible subsidy, estimates or estimates are the basis for calculating government subsidies and are related to the extent of government spending responsibilities. The accuracy of PPP project estimate preparation is particularly important. Establishing a complete set of project estimation index system is the prerequisite for accurately calculating the project estimate. Most of China's current estimates use empirical indicators.

\subsection{Develop strict PPP project completion and settlement and financial settlement system}

First, the completion settlement and final accounts system in the PPP project are related to the depreciation and transfer of assets during the project operation period. Second, the Employer (the government) will not pay for the construction cost of the contractor (social capital) during the construction period, but instead considers the project's revenue (if any) during the operation period, the project performance appraisal and incentive compatible mechanism, and the construction And operating costs, a reasonable profit margin of social capital and other factors, and the way the project operation subsidies in each operating year subsidies and payments.

\subsection{Establish systematic PPP project operation quota / indicator system}

The operation quota / index system can improve the accuracy of the calculation of the operating costs of the PPP project and provide a reliable basis for the calculation of the VfM and the government's fiscal expenditure responsibility. Prior to the implementation of the PPP project, most of China's infrastructure and public services were constructed and provided by the government. During the actual progress of PPP projects, many types of PPP projects do lack the corresponding operating quotas / indicators system, which has greatly hindered the calculation of operating costs.

\subsection{Standardize the project cost consultation service in the mode of "PPP + EPC"}

Project general contracting mode is the main trend of PPP project implementation. Under the current "PPP + EPC project" mode, it is necessary to regulate and guide project cost consulting services and provide whole-process engineering consultation for PPP projects so as to maintain and increase the value of the project. As the whole process of engineering consulting, narrow project management as the road to the design of the architects responsible for the construction of the road to PPP for the road to promote advisory-based construction, traditional menu-based project cost advisory services integrated into the investment control Core competency consulting type on behalf of the building.

\section{Conclusions}

Through the PPP model of project cost management and the demand for research, we can see that project cost management is subordinate to the project management mechanism of PPP project, but also by the PPP project contract system and performance appraisal mechanism. Complete project cost management in PPP projects is very important for reducing the out-of-control of investment in PPP projects. It is necessary to build an engineering cost management system for PPP projects in China based on international experience and provide information on supply, method and supply Aspects of the PPP project cost management to regulate, in order to promote the orderly progress of the PPP model. 


\section{References}

[1] Xing Xiaoman. Study on the Validity of Local Government's Consolation Letter to Financing Platform [J]. Theory of Theory, 2011 (11): 64-66.

[2] Zhang Ying. A Review of the Development of China's Public-Private Partnership [J]. Journal of Dong bei University of Finance and Economics, 2015,04: 20-25.

[3] Zhao Xiaojian. Understanding of PPP Financing Patterns under the New Economic Normalization [J]. Economist, 2015 (10): 128-129.

[4] Liu Shuilin. On the Goals and Methods of Government Regulation [J]. Lanzhou Academic Journal, 2016 (2): 108-114.

[5] Zhang Lei. PPP model of risk analysis [D]. Ministry of Finance Institute of Finance, 2015.

[6] Lu Tiejun. Development of British PFI Model and Its Reference Significance [J]. International Economic Cooperation, 2015, 10: 21-25. 